\title{
Assessment of mathematical models for estimating the incubation period of Puccinia recondita f. sp. tritici
}

\author{
Ocena wiarygodności modeli matematycznych do szacowania długości \\ okresu inkubacji Puccinia recondita f. sp. tritici
}

\author{
Andrzej Wójtowicz ${ }^{1 *}$, Marek Wójtowicz², Maria Pasternak ${ }^{1}$
}

\section{Summary}

The aim of the study was to compare the results of computer simulations carried out using two mathematical models developed for estimating the length of the incubation period of Puccinia recondita f. sp. tritici, the perpetrator of the leaf rust in wheat. Both models were developed using the exponential function based on the results of experiments carried out in 2013-2015. Model 1 determines the length of the incubation period based on average daily air temperatures, while model 2 based on temperature values recorded in an hourly interval. The reliability of the models was assessed by comparing the simulation results with the actual dates of onset of disease symptoms on plants inoculated in the experiments carried out in 2016-2018. The results of computer simulations using the developed models were similar with the actual dates of onset of disease symptoms. Slightly better results were obtained for the model determining the length of the incubation period based on the value of temperature recorded in the hourly interval.

Key words: Puccinia recondita, wheat, incubation period, model

\section{Streszczenie}

Celem pracy było porównanie wyników symulacji komputerowych prowadzonych z zastosowaniem dwóch modeli matematycznych opracowanych z przeznaczeniem do szacowania długości okresu inkubacji Puccinia recondita f. sp. tritici sprawcy rdzy brunatnej pszenicy. Oba modele opracowano z wykorzystaniem funkcji wykładniczej na podstawie wyników doświadczeń prowadzonych w latach $2013-2015$. Pierwszy model wyznacza długość okresu inkubacji na podstawie średnich dobowych temperatur powietrza, a drugi w oparciu o wartości temperatury rejestrowane w interwale godzinowym. Ocenę wiarygodności modeli przeprowadzono przez porównanie wyników symulacji z rzeczywistymi terminami wystąpienia objawów chorobowych na roślinach poddanych inokulacji w doświadczeniach realizowanych w latach 2016-2018. Wyniki symulacji komputerowych z zastosowaniem opracowanych modeli były zbliżone do rzeczywistych terminów wystąpienia objawów chorobowych. Nieznacznie wiarygodniejsze wyniki uzyskano dla modelu wyznaczającego długość okresu inkubacji na podstawie wartości temperatury rejestrowanej w interwale godzinowym.

Słowa kluczowe: Puccinia recondita, pszenica, okres inkubacji, model

\footnotetext{
${ }^{1}$ Instytut Ochrony Roślin - Państwowy Instytut Badawczy Władysława Węgorka 20, 60-318 Poznań

${ }^{2}$ Instytut Hodowli i Aklimatyzacji Roślin - Państwowy Instytut Badawczy

Strzeszyńska 36, 60-479 Poznań

*corresponding author: a.wojtowicz@iorpib.poznan.pl

ORCID: 0000-0003-1455-1527
} 


\section{Wstęp / Introduction}

Modele matematyczne są formalizacją mechanizmów występujących w świecie rzeczywistym (Mądry i wsp. 1999). Nie umożliwiają jednakże pełnego odwzorowania rzeczywistości. Pozwalają jedynie na przedstawienie rzeczywistości w sposób uproszczony (Kranz 1974). Pomimo to znajdują powszechne zastosowanie w różnorodnych dziedzinach nauki. W fitopatologii również są często używane zwłaszcza jako narzędzia do charakterystyki epifitoz (Arneson 2011; Stevenson i Jeger 2015; Madden i wsp. 2017). Przy realizacji tego celu wykorzystuje się zazwyczaj tzw. modele wzrostu ,growth models”, wśród których do najpopularniejszych zaliczane są monomolekularny, wykładniczy, logistyczny i Gompertza. Model monomolekularny nadaje się przede wszystkim do opisu epifitoz monocyklicznych, a pozostałe znajdują zastosowanie w modelowaniu epifitoz policyklicznych, z tym że model wykładniczy dobrze odwzorowuje jedynie jej początkową fazę (Jeger 2004; Contreras-Medina i wsp. 2009). Przegląd literatury poświęconej zagadnieniu modelowania matematycznego w dziedzinie fitopatologii dostarcza również licznych przykładów wykorzystania modeli do opisywania poszczególnych etapów procesu chorobowego (Carisse i wsp. 2000; Dalla Pria i wsp. 2006; Gamliel-Atinsky i wsp. 2009; Wakeham i Kennedy 2010; Launay i wsp. 2014).

Kluczowym zagadnieniem w badaniach nad modelowaniem zjawisk i procesów jest sprawdzenie wiarygodności opracowanych modeli. Polega to na porównaniu wyników symulacji przeprowadzonych $\mathrm{z}$ zastosowaniem modelu z wynikami obserwacji przeprowadzonymi na docelowej populacji warunków środowiskowych, to znaczy innej niż ta, z której obserwacje wykorzystano do opracowania modelu (Mądry i wsp. 1999). Zgodnie z tym zaleceniem realizacja celu pracy, jakim było sprawdzenie wiarygodności modeli inkubacji sprawcy rdzy brunatnej pszenicy opracowanych z wykorzystaniem danych zgromadzonych w latach 2013-2015 polegała na porównaniu wyników symulacji z wynikami obserwacji przeprowadzonych w latach 2016-2018.

\section{Materiały i metody / Materials and methods}

Badania przeprowadzono z zastosowaniem dwóch modeli okresu inkubacji sprawcy rdzy brunatnej pszenicy. Pierwszy, opracowany w oparciu o wyniki eksperymentów realizowanych w latach 2013-2015 (Wójtowicz i wsp. 2020), wyznacza długość okresu inkubacji na podstawie średnich dobowych temperatur powietrza. Drugi jest efektem przekształcenia pierwszego do postaci umożliwiającej szacowanie okresu inkubacji na podstawie temperatury rejestrowanej w interwale godzinowym. Przy wyborze funkcji do opisania zależności między analizowanymi parametrami wzorowano się na publikacji Behlau i wsp. (2017), którzy zastosowali takie równanie do oceny wpływu miedzi na powierzchnię pod krzywą nasilenia raka cytrusów oraz na liczbę owoców pomarańczy porażonych przez Xanthomonas citri subsp. citri. Zależność pomiędzy temperaturą a długością okresu inkubacji w obu zastosowanych modelach opisano w następujący sposób:

$$
\begin{aligned}
& I_{d}=5,992963+\exp \left(3,20964+0,15866 \times T_{d}\right) \\
& I_{h}=154,5047+\exp \left(6,50638-0,17310 \times T_{h}\right)
\end{aligned}
$$

gdzie:

$\mathrm{I}_{\mathrm{d}}$ - okres inkubacji Puccinia recondita [dni],

$\mathrm{I}_{\mathrm{h}}$ - okres inkubacji Puccinia recondita [godziny],

$\mathrm{T}_{\mathrm{d}}$ - temperatura dobowa $\left[{ }^{\circ} \mathrm{C}\right]$,

$\mathrm{T}_{\mathrm{h}}$ - temperatura zmierzona $\mathrm{w}$ interwale godzinowym $\left[{ }^{\circ} \mathrm{C}\right]$.

$\mathrm{Na}$ potrzeby symulacji komputerowych opracowane modele $\left[I_{d}, I_{h}\right]$ przekształcono do postaci $1 / I_{d}$ oraz $1 / I_{h}$. W tej formie, na podstawie temperatury, modele umożliwiają wyznaczenie terminów wystąpienia objawów chorobowych. Realizacja tego zadania polegała na dodawaniu w interwale dobowym kolejnych wartości $1 / \mathrm{I}_{\mathrm{d}}$ (z wykorzystaniem modelu pierwszego) oraz w interwale godzinowym kolejnych wartości 1// $\mathrm{I}_{\mathrm{h}}$ (z wykorzystaniem modelu drugiego) od dnia inokulacji do dnia, w którym suma obliczeń osiągała lub przekraczała wartość równą jedności.

Ocenę wiarygodności opracowanych modeli przeprowadzono przez porównanie wyników symulacji z rzeczywistymi terminami wystąpienia objawów chorobowych. Do badań wybrano odmianę Turnia o podatności 6,9 (Gacek 2013). Dziesięciodniowe siewki pszenicy tej odmiany inokulowano zawiesiną urediniospor Puccini recondita f. sp. tritici, a następnie przetrzymywano w temperaturze $15^{\circ} \mathrm{C}$ w workach foliowych gwarantujących zwilżenie liści niezbędne dla efektywnej infekcji. Koncentracja urediniospor w zastosowanym inokulum wynosiła 3,9 $\times 10^{5}$ zarodników/ $\mathrm{ml}$. Po 24 godzinach od inokulacji wyjmowano rośliny z worków foliowych, przenoszono do warunków polowych i poddawano codziennej obserwacji kontynuowanej do dnia wystąpienia pierwszych urediniów. Badania prowadzono w latach 2016-2018. Liczba doświadczeń realizowanych w latach 2016, 2017 i 2018 wynosiła odpowiednio: 22, 21 i 22 . Wszystkie eksperymenty przeprowadzono w 3 powtórzeniach. Za każdym razem do 3 doniczek o średnicy $10 \mathrm{~cm}$ wysiewano po 60 ziarniaków pszenicy. Dane meteorologiczne niezbędne do oceny wiarygodności modeli, pobrano ze strony internetowej dostępnej pod adresem https:// weather.gladstonefamily.net/site/EPPO.

Wiarygodność zaproponowanych modeli oceniono z zastosowaniem modułu ,estymacja nieliniowa” dostępnego w pakiecie STATISTICA 12 na podstawie wartości współczynników determinacji $\mathrm{R}^{2}$ funkcji liniowych opisujących związek symulowanych i obserwowanych okresów inkubacji oraz z zastosowaniem diagramu Taylora na podstawie odległości pomiędzy punktem przedstawiajacm wyniki obserwacji i punktami przedstawiającymi wyniki działania analizowanych modeli (Taylor 2001). 


\section{Wyniki i dyskusja / Results and discussion}

W 2016 roku długość okresu inkubacji $P$. recondita mieściła się w zakresie 6-13 dni (tab. 1). W marcu i kwietniu objawy chorobowe wystąpiły odpowiednio 12-13 oraz 11-13 dni po inokulacji. W maju i czerwcu okres inkubacji sprawcy rdzy brunatnej wynosił odpowiednio: 7-11 oraz 7-8 dni. W lipcu i sierpniu odnotowano skrócenie inkubacji do 7 dni, a we wrześniu objawy rdzy wystąpiły $6-8$ dni po inokulacji.

W 2017 roku liczba dni od inokulacji do wystąpienia objawów chorobowych wynosiła od 6 do 16 (tab. 2). W marcu okres inkubacji zawierał się w zakresie 12-16, a w kwietniu 14-15 dni. W maju objawy rdzy odnotowano 7-9, a w czerwcu 7-8 dni po inokulacji. W lipcu okres inkubacji wynosił 6-7, w sierpniu 6, a we wrześniu 9-12 dni.

W 2018 roku długość okresu inkubacji $P$. recondita zawierała się w przedziale 6-13 dni (tab. 3). W kwietniu licz- ba dni od inokulacji do wystąpienia objawów rdzy brunatnej wynosiła 8-11 dni, a w maju i czerwcu odpowiednio 6-7 i 6-8 dni. W lipcu objawy choroby odnotowano 6-7 dni po inokulacji, we wrześniu liczba dni od inokulacji do wystąpienia objawów rdzy brunatnej zawierała się w przedziale 7-12, a w październiku w przedziale 8-13.

Terminy wystąpienia objawów rdzy brunatnej pokrywały się z wynikami symulacji komputerowych lub nieznacznie od nich odbiegały (tab. 1-3).

Całkowitą zgodność symulacji prowadzonych z zastosowaniem modelu $1 \mathrm{z}$ wynikami obserwacji odnotowano trzydziestodwukrotnie (49\%). Jeden dzień różnicy stwierdzono dziewiętnastokrotnie (29\%), a dwa dni różnicy siedmiokrotnie (11\%). Również siedmiokrotnie (11\%) odnotowano trzy dni różnicy pomiędzy wynikami symulacji i obserwacji. Zastosowanie modelu 2 skutkowało nieznacznymi zmianami uzyskanych wyników. W tym przypadku całkowitą zgodność symulacji z wynikami obserwacji odnotowano

Tabela 1. Porównanie terminów rzeczywistego wystąpienia objawów rdzy brunatnej pszenicy w 2016 roku z wynikami symulacji przeprowadzonych z zastosowaniem zaproponowanych modeli

Table 1. Comparison of observed occurrence of leaf rust symptoms in 2016 with the results of simulations carried out using the models proposed

\begin{tabular}{|c|c|c|c|c|c|c|}
\hline \multirow[b]{2}{*}{$\begin{array}{l}\text { Lp. } \\
\text { No. }\end{array}$} & \multirow[b]{2}{*}{$\begin{array}{c}\text { Data inokulacji } \\
180 \text { roślin } \\
\text { Date of inoculation } \\
180 \text { plants }\end{array}$} & \multirow[b]{2}{*}{$\begin{array}{c}\text { Rzeczywisty okres } \\
\text { inkubacji } \\
\text { [dni] } \\
\text { Observed } \\
\text { incubation period } \\
\text { [days] }\end{array}$} & \multicolumn{2}{|c|}{ Model 1} & \multicolumn{2}{|c|}{ Model 2} \\
\hline & & & $\begin{array}{c}\text { symulowany okres } \\
\text { inkubacji [dni] } \\
\text { simulated } \\
\text { incubation period } \\
\text { [days] }\end{array}$ & $\begin{array}{l}\text { niezgodność } \\
\text { [dni] } \\
\text { incompatibility } \\
\text { [days] }\end{array}$ & $\begin{array}{c}\text { symulowany okres } \\
\text { inkubacji [dni] } \\
\text { simulated } \\
\text { incubation period } \\
\text { [days] }\end{array}$ & $\begin{array}{c}\text { niezgodność } \\
\text { [dni] } \\
\text { incompatibility } \\
\text { [days] }\end{array}$ \\
\hline 1. & 23.03 .2016 & 13 & 12 & -1 & 12 & -1 \\
\hline 2. & 30.03 .2016 & 12 & 10 & -2 & 10 & -2 \\
\hline 3. & 06.04 .2016 & 12 & 10 & -2 & 11 & -1 \\
\hline 4. & 14.04 .2016 & 13 & 12 & -1 & 13 & 0 \\
\hline 5. & 21.04 .2016 & 13 & 12 & -1 & 12 & -1 \\
\hline 6. & 28.04 .2016 & 11 & 9 & -2 & 9 & -2 \\
\hline 7. & 05.05 .2016 & 7 & 7 & 0 & 8 & 1 \\
\hline 8. & 12.05 .2016 & 11 & 9 & -2 & 9 & -2 \\
\hline 9. & 18.05 .2016 & 7 & 7 & 0 & 7 & 0 \\
\hline 10. & 02.06 .2016 & 7 & 7 & 0 & 7 & 0 \\
\hline 11. & 09.06 .2016 & 8 & 7 & -1 & 8 & 0 \\
\hline 12. & 16.06 .2016 & 8 & 7 & -1 & 7 & -1 \\
\hline 13. & 23.06 .2016 & 7 & 7 & 0 & 7 & 0 \\
\hline 14. & 30.06 .2016 & 8 & 7 & -1 & 7 & -1 \\
\hline 15. & 07.07 .2016 & 7 & 7 & 0 & 7 & 0 \\
\hline 16. & 14.07 .2016 & 7 & 7 & 0 & 7 & 0 \\
\hline 17. & 19.07 .2016 & 7 & 7 & 0 & 7 & 0 \\
\hline 18. & 28.07 .2016 & 7 & 7 & 0 & 7 & 0 \\
\hline 19. & 03.08 .2016 & 7 & 7 & 0 & 8 & 1 \\
\hline 20. & 06.09 .2016 & 6 & 7 & 1 & 7 & 1 \\
\hline 21. & 15.09 .2016 & 8 & 8 & 0 & 8 & 0 \\
\hline 22. & 22.09 .2016 & 8 & 8 & 0 & 8 & 0 \\
\hline
\end{tabular}


Tabela 2. Porównanie terminów rzeczywistego wystąpienia objawów rdzy brunatnej pszenicy w 2017 roku z wynikami symulacji przeprowadzonych z zastosowaniem zaproponowanych modeli

Table 2. Comparison of observed occurrence of leaf rust symptoms in 2017 with the results of simulations carried out using the models proposed

\begin{tabular}{|c|c|c|c|c|c|c|}
\hline \multirow[b]{2}{*}{$\begin{array}{l}\text { Lp. } \\
\text { No. }\end{array}$} & \multirow[b]{2}{*}{$\begin{array}{c}\text { Data inokulacji } \\
180 \text { roślin } \\
\text { Date of inoculation } \\
180 \text { plants }\end{array}$} & \multirow[b]{2}{*}{$\begin{array}{c}\text { Rzeczywisy okres } \\
\text { inkubacji } \\
\text { [dni] } \\
\text { Observed } \\
\text { incubation period } \\
\text { [days] }\end{array}$} & \multicolumn{2}{|c|}{ Model 1} & \multicolumn{2}{|c|}{ Model 2} \\
\hline & & & $\begin{array}{l}\text { symulowany okres } \\
\text { inkubacji [dni] } \\
\text { simulated } \\
\text { incubation period } \\
\text { [days] }\end{array}$ & $\begin{array}{c}\text { niezgodność } \\
\text { [dni] } \\
\text { incompatibility } \\
\text { [days] }\end{array}$ & $\begin{array}{l}\text { symulowany okres } \\
\text { inkubacji [dni] } \\
\text { simulated } \\
\text { incubation period } \\
\text { [days] }\end{array}$ & $\begin{array}{c}\text { niezgodność } \\
\text { [dni] } \\
\text { incompatibility } \\
\text { [days] }\end{array}$ \\
\hline 1. & 13.03 .2017 & 16 & 13 & -3 & 14 & -2 \\
\hline 2. & 22.03 .2017 & 12 & 10 & -2 & 11 & -1 \\
\hline 3. & 29.03 .2017 & 12 & 9 & -3 & 10 & -2 \\
\hline 4. & 20.04 .2017 & 15 & 12 & -3 & 12 & -3 \\
\hline 5. & 27.04 .2017 & 14 & 11 & -3 & 12 & -2 \\
\hline 6. & 08.05 .2017 & 9 & 9 & 0 & 9 & 0 \\
\hline 7. & 15.05 .2017 & 7 & 7 & 0 & 8 & 1 \\
\hline 8. & 25.05 .2017 & 7 & 7 & 0 & 7 & 0 \\
\hline 9. & 01.06 .2017 & 7 & 7 & 0 & 8 & 1 \\
\hline 10. & 06.06 .2017 & 7 & 7 & 0 & 7 & 0 \\
\hline 11. & 12.06 .2017 & 8 & 7 & -1 & 8 & 0 \\
\hline 12. & 19.06 .2017 & 7 & 7 & 0 & 7 & 0 \\
\hline 13. & 29.06 .2017 & 8 & 7 & -1 & 8 & 0 \\
\hline 14. & 06.07 .2017 & 7 & 7 & 0 & 7 & 0 \\
\hline 15. & 12.07 .2017 & 7 & 7 & 0 & 7 & 0 \\
\hline 16. & 20.07 .2017 & 7 & 7 & 0 & 7 & 0 \\
\hline 17. & 26.07 .2017 & 6 & 7 & 1 & 7 & 1 \\
\hline 18. & 02.08 .2017 & 6 & 7 & 1 & 7 & 1 \\
\hline 19. & 13.09 .2017 & 9 & 9 & 0 & 9 & 0 \\
\hline 20. & 20.09 .2017 & 9 & 8 & -1 & 9 & 0 \\
\hline 21. & 27.09 .2017 & 12 & 9 & -3 & 10 & -2 \\
\hline
\end{tabular}

trzydziestokrotnie (46\%). Jeden dzień różnicy stwierdzono dwudziestoczterokrotnie (37\%), a dwa dni różnicy ośmiokrotnie (12\%). Natomiast trzydniowe różnice wystąpiły trzykrotnie (4\%).

Przedstawiona graficznie na rysunku 1. relacja pomiędzy rzeczywistym i symulowanym okresem inkubacji została wyrażona w formie następujących równań:

$$
\begin{aligned}
& \mathrm{RI}=1,4344 \times \mathrm{SI}_{[\mathrm{d}]}-2,9375\left(\mathrm{R}^{2}=0,88\right) \\
& \mathrm{RI}=1,3509 \times \mathrm{SI}_{[\mathrm{h}]}-2,6972\left(\mathrm{R}^{2}=0,88\right)
\end{aligned}
$$

gdzie:

RI - rzeczywisty okres inkubacji,

$\mathrm{SI}_{[\mathrm{d}]}$ - okres inkubacji symulowany z zastosowaniem modelu 1 na podstawie średnich dobowych temperatur powietrza, $\mathrm{SI}_{[\mathrm{h}]}$ - okres inkubacji symulowany z zastosowaniem modelu 2 na podstawie temperatury powietrza rejestrowanej w interwale godzinowym.
Wartości parametrów statystycznych równań opisujących zgodność pomiędzy rzeczywistym i symulowanym okresem inkubacji zebrano w tabeli 4.

Na podstawie wyników eksperymentów przeprowadzonych w latach 2016-2018 wykazano dużą zbieżność rzeczywistych i symulowanych terminów wystąpienia objawów rdzy brunatnej pszenicy. W następstwie zastosowania modelu 1 odnotowano 78\% symulacji komputerowych, których wyniki pokrywały się z wynikami obserwacji lub różniły się od nich nie więcej niż o jeden dzień. Jeszcze lepsze rezultaty uzyskano po zastosowaniu modelu 2, kiedy liczba symulacji nieróżniących się od wyników obserwacji więcej niż jeden dzień osiągnęła wartość 83\%. Potwierdzeniem przewagi modelu 2 nad modelem 1 w szacowaniu długości okresu inkubacji są wyniki uzyskane z zastosowaniem diagramu Taylora (rys. 2). Diagram Taylora (Taylor 2001) umożliwia graficzne przedstawienie zgodności wyników symulacji z wynikami 
Tabela 3. Porównanie terminów rzeczywistego wystąpienia objawów rdzy brunatnej pszenicy w 2018 roku z wynikami symulacji przeprowadzonych z zastosowaniem zaproponowanych modeli

Table 3. Comparison of observed occurrence of leaf rust symptoms in 2018 with the results of simulations carried out using the models proposed

\begin{tabular}{|c|c|c|c|c|c|c|}
\hline \multirow[b]{2}{*}{$\begin{array}{l}\text { Lp. } \\
\text { No. }\end{array}$} & \multirow[b]{2}{*}{$\begin{array}{c}\text { Data inokulacji } \\
180 \text { roślin } \\
\text { Date of inoculation } \\
180 \text { plants }\end{array}$} & \multirow{2}{*}{$\begin{array}{l}\text { Rzeczywisy okres } \\
\text { inkubacji } \\
\text { [dni] } \\
\text { Observed } \\
\text { incubation period } \\
\text { [days] }\end{array}$} & \multicolumn{2}{|c|}{ Model 1} & \multicolumn{2}{|c|}{ Model 2} \\
\hline & & & $\begin{array}{l}\text { symulowany okres } \\
\text { inkubacji [dni] } \\
\text { simulated } \\
\text { incubation period } \\
\text { [days] }\end{array}$ & $\begin{array}{l}\text { niezgodność } \\
\text { [dni] } \\
\text { incompatibility } \\
\text { [days] }\end{array}$ & $\begin{array}{l}\text { symulowany okres } \\
\text { inkubacji [dni] } \\
\text { simulated } \\
\text { incubation period } \\
\text { [days] }\end{array}$ & $\begin{array}{c}\text { niezgodność } \\
\text { [dni] } \\
\text { incompatibility } \\
\text { [days] }\end{array}$ \\
\hline 1. & 09.04 .2018 & 8 & 8 & 0 & 8 & 0 \\
\hline 2. & 19.04 .2018 & 8 & 9 & 1 & 9 & 1 \\
\hline 3. & 26.04 .2018 & 11 & 8 & -3 & 8 & -3 \\
\hline 4. & 07.05 .2018 & 7 & 7 & 0 & 7 & 0 \\
\hline 5. & 21.05 .2018 & 7 & 7 & 0 & 7 & 0 \\
\hline 6. & 28.05 .2018 & 6 & 6 & 0 & 7 & 1 \\
\hline 7. & 05.06 .2018 & 6 & 7 & 1 & 7 & 1 \\
\hline 8. & 14.06 .2018 & 6 & 7 & 1 & 7 & 1 \\
\hline 9. & 21.06.2018 & 8 & 8 & 0 & 8 & 0 \\
\hline 10. & 26.06 .2018 & 7 & 7 & 0 & 7 & 0 \\
\hline 11. & 03.07 .2018 & 6 & 7 & 1 & 7 & 1 \\
\hline 12. & 10.07 .2018 & 7 & 7 & 0 & 7 & 0 \\
\hline 13. & 18.07 .2018 & 6 & 7 & 1 & 7 & 1 \\
\hline 14. & 24.07 .2018 & 6 & 6 & 0 & 7 & 1 \\
\hline 15. & 31.07 .2018 & 7 & 6 & -1 & 7 & 0 \\
\hline 16. & 12.09 .2018 & 7 & 7 & 0 & 8 & 1 \\
\hline 17. & 19.09 .2018 & 12 & 9 & -3 & 9 & -3 \\
\hline 18. & 26.09 .2018 & 12 & 10 & -2 & 10 & -2 \\
\hline 19. & 03.10 .2018 & 9 & 9 & 0 & 9 & 0 \\
\hline 20. & 10.10 .2018 & 8 & 8 & 0 & 9 & 1 \\
\hline 21. & 16.10 .2018 & 13 & 11 & -2 & 12 & -1 \\
\hline 22. & 24.10 .2018 & 12 & 11 & -1 & 11 & -1 \\
\hline
\end{tabular}

Tabela 4. Parametry równań opisujących zgodność wyników symulacji i obserwacji okresu inkubacji sprawcy rdzy brunatnej pszenicy Table 4. Parameters of the equation representing exact agreement between observed and simulated latency period of wheat leaf rust

\begin{tabular}{|c|c|c|c|c|}
\hline \multirow{3}{*}{ Model } & \multirow{3}{*}{$\begin{array}{l}\text { Równanie } \\
\text { Equation }\end{array}$} & \multicolumn{3}{|c|}{$\begin{array}{c}\text { Parametry statystyczne } \\
\text { Values of statistical parameters }\end{array}$} \\
\hline & & \multicolumn{3}{|c|}{$\mathrm{p}$} \\
\hline & & $\begin{array}{c}\text { przesunięcie } \\
\text { intercept }\end{array}$ & $\begin{array}{c}\text { nachylenie } \\
\text { slope }\end{array}$ & $\mathrm{R}^{2}$ \\
\hline 1 & $y=1,4344 x-2,9375$ & 0,000002 & 0,000000 & 0,88 \\
\hline 2 & $\mathrm{y}=1,3509 \mathrm{x}-2,6972$ & 0,000006 & 0,000000 & 0,88 \\
\hline
\end{tabular}

obserwacji na podstawie trzech miar charakteryzujących jakość modelu: korelacji Pearsona, średniego błędu kwadratowego i odchylenia standardowego. Im mniejsza odległość pomiędzy punktem charakteryzującym wyniki działania modelu a punktem charakteryzującym wyniki obserwacji, tym model trafniej odzwierciedla rzeczywistość.
Przedstawione w niniejszej pracy wyniki są zgodne z prezentowanymi wcześniej rezultatami badań podejmującymi tematykę wpływu temperatury na rozwój patogenów (Hong i Fitt 1996; Xu 1996, 1999; Becktell i wsp. 2005; Ghini i wsp. 2011; Leclerc i wsp. 2014). Wymienieni autorzy zgodnie wskazują na kluczową rolę temperatury 

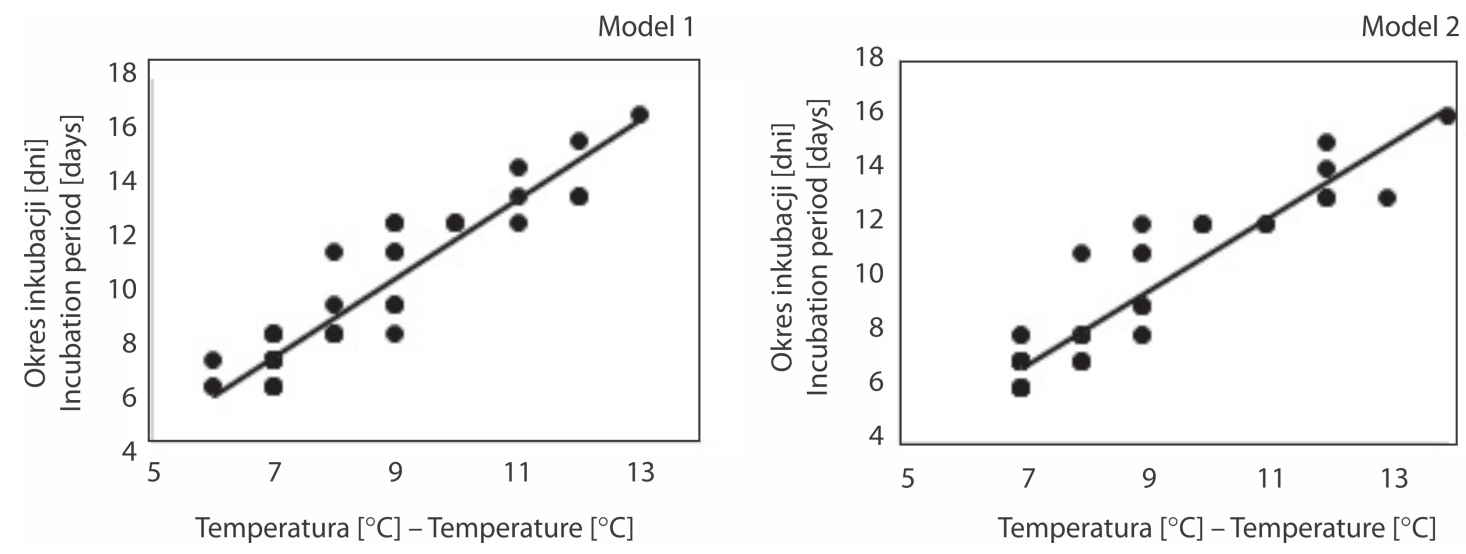

Rys. 1. Zgodność rzeczywistego i symulowanego okresu inkubacji Puccinia recondita pszenicy

Fig. 1. Comparison of observed and simulated incubation period of Puccinia recondita

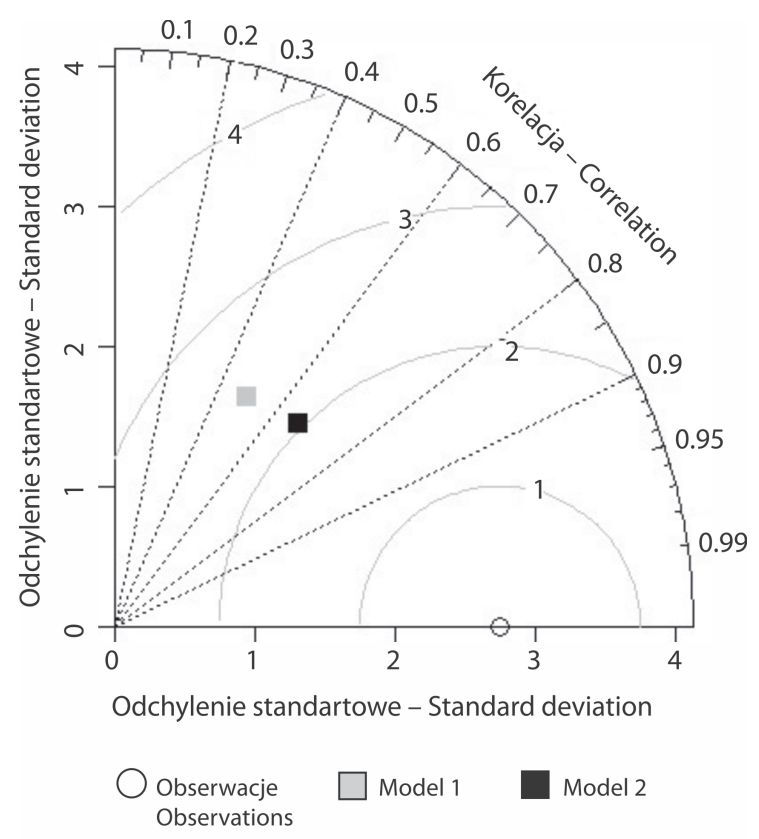

Rys. 2. Diagram Taylora ilustrujący statystyki uzyskane z porównania wyników obserwacji i symulacji uzyskanych z zastosowaniem dwóch modeli okresu inkubacji. Model 1 wyznacza długość okresu inkubacji na podstawie średnich dobowych temperatur powietrza, a model $2 \mathrm{w}$ oparciu o wartości temperatury rejestrowane $\mathrm{w}$ interwale godzinowym

Fig. 2. Taylor diagram illustrating the statistics obtained on comparing observed values and estimates produced by two models of incubation period. Model 1 determines the length of the incubation period based on average daily air temperatures, and model 2 based on temperature values recorded in an hourly interval

w modyfikacji długości okresu inkubacji. Udowodniona na podstawie przytoczonych wyników pozytywna ocena wiarygodności opracowanych modeli stanowi potwierdzenie badań realizowanych w latach 2010-2011 (Wójtowicz 2012) i 2013-2015 (Wójtowicz i wsp. 2017), w których również wykazano z zastosowaniem funkcji wykładniczej możliwość wiarygodnego szacowania terminu wystąpienia objawów rdzy brunatnej pszenicy na podstawie temperatury. Zastosowanie innych funkcji do szacowania długości okresu inkubacji na podstawie temperatury podejmowane było również z sukcesem. Karolewski i wsp. (2002) w badaniach nad cylindrosporiozą zastosowali funkcję logistyczną, a Räder (2007) oraz Räder i wsp. (2007) do szacowania terminu wystąpienia objawów rdzy brunatnej na życie zastosowali zmodyfikowaną wersję funkcji beta. Z kolei Becktell i wsp. (2005) w badaniach nad porażeniem petunii przez Phytophthora infestans zastosowali funkcję wielomianową drugiego stopnia. Takie rozwiązanie można odnaleźć również w doniesieniach na temat infekcji truskawki przez Colletotrichum spp. (King i wsp. 1997) oraz rododendronu przez Thekopsora minima (Pfister i wsp. 2004).

Większa zgodność wyników obserwacji z wynikami symulacji przeprowadzonych $\mathrm{w}$ oparciu o wartości temperatury rejestrowanej $\mathrm{w}$ interwale godzinowym w porównaniu z symulacjami prowadzonymi na podstawie średnich wartości temperatury dobowej, wskazuje na możliwości zwiększenia wiarygodności modeli i stanowi przyczynek do przeprowadzenia szerszych badań w tym zakresie. Literatura dotycząca modelowania patogenów nie obfituje bowiem w liczne przykłady umożliwiające rozstrzygnięcie tej kwestii.

\section{Wnioski / Conclusions}

1. Uzyskane wyniki pozwalają na pozytywną ocenę wiarygodności opracowanych modeli, przeznaczonych do szacowania na podstawie temperatury długości okresu inkubacji $P$. recondita $\mathrm{f}$. sp. tritici.

2. Udowodniona na podstawie wyników przeprowadzonych doświadczeń duża wiarygodność opracowanych modeli, wskazuje na możliwości zastosowania ich do szacowania wpływu przewidywanych zmian klimatu na zagrożenie pszenicy przez $P$. recondita $\mathrm{f}$. sp. tritici. 


\section{Literatura / References}

Arneson P.A. 2011. Plant Disease Epidemiology: Temporal Aspects (Revised 2011). Plant Health Instructor. American Phytopathological Society. DOI: 10.1094/PHI-A-2001-0524-01

Becktell M.C., Daughtrey M.L., Fry W.E. 2005. Temperature and leaf wetness requirements for pathogen establishment, incubation period, and sporulation of Phytophthora infestans on Petunia $\times$ hybrida. Plant Disease 89 (9): 975-979. DOI: 10.1094/PD-89-0975

Behlau F., Scandelai L.H.M., da Silva Junior G.J., Lanza F.E. 2017. Soluble and insoluble copper formulations and metallic copper rate for control of citrus canker on sweet orange trees. Crop Protection 94: 185-191. DOI: 10.1016/j.cropro.2017.01.003

Carisse O., Bourgeois G., Duthie J.A. 2000. Influence of temperature and leaf wetness duration on infection of strawberry leaves by $M y$ cosphaerella fragariae. Phytopathology 90 (10): 1120-1125. DOI: 10.1094/PHYTO.2000.90.10.1120

Contreras-Medina L.M., Torres-Pacheco I., Guevara-González R.G., Romero-Troncoso R.J., Terol-Villalobos I.R., Osornio-Rios R.A. 2009. Mathematical modeling tendencies in plant pathology. African Journal of Biotechnology 8 (25): 7399-7408.

Dalla Pria M., Christiano R.C.S., Furtado E.L., Amorim L., Bergamin A. 2006. Effect of temperature and leaf wetness duration on infection of sweet oranges by Asiatic citrus canker. Plant Pathology 55 (5): 657-663. DOI: 10.1111/j.1365-3059.2006.01393.x

Gacek E. 2013. Lista opisowa odmian. Centralny Ośrodek Badania Odmian Roślin Uprawnych, Słupia Wielka, 1174 ss.

Gamliel-Atinsky E., Sztejnberg A., Maymon M., Vintal H., Shtienberg D., Freeman S. 2009. Infection dynamics of Fusarium mangiferae, causal agent of mango malformation disease. Phytopathology 99 (6): 775-781. DOI: 10.1094/PHYTO-99-6-0775

Ghini R., Hamada E., Pedro Júnior M.J., Gonçalves R.R.V. 2011. Incubation period of Hemileia vastatrix in coffee plants in Brazil simulated under climate change. Summa Phytopathologica 37 (2): 85-93. DOI: 10.1590/S0100-54052011000200001

Hong C., Fitt B. 1996. Factors affecting the incubation period of dark leaf and pod spot (Alternaria brassicae) on oilseed rape (Brassica napus). European Journal of Plant Pathology 102: 545-553. DOI: 10.1007/BF01877021

Jeger M.J. 2004. Analysis of disease progress as a basis for evaluating disease management practices. Annual Review of Phytopathology 42: 61-82. DOI: 10.1146/annurev.phyto.42.040803.140427

Karolewski Z., Evans N., Fitt B.D.L., Todd A.D., Baierl A. 2002. Sporulation of Pyrenopeziza brassicae (light leaf spot) on oilseed rape (Brassica napus) leaves inoculated with ascospores or conidia at different temperatures and wetness durations. Plant Pathology 51 (5): 654-665. DOI: 10.1046/j.1365-3059.2002.00746.x

King W.T., Madden L.V., Ellis M.A., Wilson L.L. 1997. Effects of temperature on sporulation and latent period of Colletotrichum spp. infecting strawberry fruit. Plant Disease 81 (1): 77-84. DOI: 10.1094/PDIS.1997.81.1.77

Kranz J. (red.). 1974. Epidemics of Plant Diseases: Mathematical Analysis and Modeling. Springer-Verlag, Berlin, Heidelberg. ISBN 9783-642-96220-2. DOI: 10.1007/978-3-642-96220-2

Launay M., Caubel J., Bourgeois G., Huard F., Cortazar-Atauri I.G., Bancal M., Brisson N. 2014. Climatic indicators for crop infection risk: Application to climate change impacts on five major foliar fungal diseases in Northern France. Agriculture, Ecosystems \& Environment 197: 147-158. DOI: 10.1016/j.agee.2014.07.020

Leclerc M., Dore T., Gilligan C.A., Lucas P., Filipe J. 2014. Estimating the delay between host infection and disease (incubation period) and assessing its significance to the epidemiology of plant diseases. PLoS ONE 9 (1): e86568. DOI: 10.1371/journal.pone.0086568

Madden L.V., Hughes G., van den Bosch F. 2017. The Study of Plant Disease Epidemics. The American Phytopathological Society, St. Paul, Minnesota, 432 ss. ISBN 978-0-89054-505-8. DOI: 10.1094/9780890545058

Mądry W., Zieliński W., Rozbicki J., Wyszyński Z. 1999. Kalibracja i sprawdzanie działania symulacyjnych modeli roślin uprawnych. Roczniki Nauk Rolniczych, Seria A, Produkcja Roślinna 114 (1-2): 25-40.

Pfister S.E., Halik S., Bergdahl D.R. 2004. Effect of temperature on Thekopsora minima urediniospores and uredinia. Plant Disease 88 (4): 359-362. DOI: 10.1094/PDIS.2004.88.4.359

Räder T. 2007. Entwicklung eines Prognose- und Entscheidungsmodells zur Braunrostbekämpfung in Winterroggen und Winterweizen. Universität Hannover, 135 ss. http://d-nb.info/983880298/34 [dostęp: 5.02.2020].

Räder T., Racca P., Jörg E., Hau B. 2007. PUCREC/PUCTRI - a decision support system for the control of leaf rust of winter wheat and winter rye. Bullettin OEPP/EPPO Bullettin 37 (2): 378-382. DOI: 10.1111/j.1365-2338.2007.01140.x

Stevenson K.L., Jeger M.J. 2015. Exercises in Plant Disease Epidemiology. Second Edition. The American Phytopathological Society, St. Paul, Minnesota, 276 ss. ISBN 978-0-89054-440-2.

Taylor K.E. 2001. Summarizing multiple aspects of model performance in a single diagram. Journal of Geophysical Research 106 (D7): 7183-7192. DOI: $10.1029 / 2000 J D 900719$

Wakeham A.J., Kennedy R. 2010. Risk assessment methods for the ringspot pathogen Mycosphaerella brassicicola in vegetable Brassica crops. Plant Disease 94 (7): 851-859. DOI: 10.1094/PDIS-94-7-0851

Wójtowicz A. 2012. Opracowanie i walidacja modelu szacującego pojawienie się objawów chorobowych powodowanych przez Puccinia recondita f. sp. tritici. [Validation of a model for estimation appearance of symptoms caused by Puccinia recondita f. sp. tritici]. Progress in Plant Protection/Postępy w Ochronie Roślin 52 (3): 680-683. DOI: 10.14199/ppp-2012-119

Wójtowicz A., Wójtowicz M., Pasternak M., Pieczul K., Świerczyńska I., Sadowska K. 2020. Wpływ warunków termicznych na okres inkubacji rdzy brunatnej pszenicy. [Effect of thermal conditions on the incubation period of wheat leaf rust]. Progress in Plant Protection 60 (1): 57-64. DOI: 10.14199/ppp-2020-008

Wójtowicz A., Wójtowicz M., Sigvald R., Pasternak M. 2017. Predicting the effects of climate change on latency period of wheat leaf rust in western Poland. Acta Agriculturae Scandinavica, Section B - Soil \& Plant Science 67 (3): 223-234. DOI: 10. $1080 / 09064710.2016 .1248481$

$\mathrm{Xu}$ X. 1996. The effects of constant and fluctuating temperatures on the length of the incubation period of apple powdery mildew (Podosphaera leucotricha). Plant Pathology 45 (5): 924-932. DOI: 10.1111/j.1365-3059.1996.tb02903.x

Xu X. 1999. Effects of temperature on the length of the incubation period of rose powdery mildew (Sphaerotheca pannosa var. rosae). European Journal of Plant Pathology 105: 13-21. DOI: 10.1023/A:1008666605593 